\title{
WHY ENFORCEMENT AGAINST EXCESSIVE PRICING IN THE RUSSIAN FEDERATION IS NOT SUFFICIENTLY SUCCESSFUL?'
}

\author{
Avdasheva Svetlana B. \\ Doctor of Economic Sciences, Professor of the Applied Economics Department \\ and Institute for Industrial and Market Studies (IIMS), NRU HSE. \\ Address: National Research University Higher School of Economics. \\ 20 Miasnitskaya, 101000, Moscow, Russian Federation. \\ E-mail: avdash@hse.ru
}

\section{Korneeva Dina V.}

$\mathrm{PhD}$ (in Econ.), Junior Research fellow of IIMS, NRU HSE.

Address: National Research University Higher School of Economics.

20 Miasnitskaya, 101000, Moscow, Russian Federation.

E-mail: dkorneeva@hse.ru

\begin{abstract}
In developed competition jurisdictions, excessive pricing is more a subject of academic and expert discussions than an actively used instrument of competition enforcement. Russian competition enforcement is an exception in this regard. During the last ten years the Russian competition authority, the Federal Antirust Service (FAS), made several hundred decisions on the violation of rules prohibiting excessive pricing. The question remains whether Russian enforcement is consistent with international experiences, and which part of enforcement limits a positive welfare effect. To achieve this objective the article explains the targets of excessive price enforcement, the legal standard for excessive pricing, and remedies applied in Russian competition law. The main conclusion is that the selection of targets does not generally contradict the objectives of competition enforcement. There are clear theories of harm specific to two of the main target groups: dominant exporting companies that apply third-price discrimination in the domestic market vis-à-vis export markets, and dominant companies that increase prices after deregulation, in case there is no new entry. Standards for proving price excessiveness represent a questionable part of enforcement, and they often turn out to be weak under judicial review. The application of either lower or higher standards for establishing price excessiveness results in decreasing the deterrence effect. A fear of decreasing deterrence explains the recent shift from ex-post intervention to ex-ante price remedies.
\end{abstract}

Keywords: excessive price; enforcement; competition law; price-cost margin; comparable markets; remedies.

Citation: Avdasheva, S.B. \& Korneeva, D.V. (2017). Why Enforcement against Excessive Pricing in the Russian Federation is not Sufficiently Successful? Public Administration Issues, Special Issue (electronic edition), pp. 117-133 (in English); doi: 10.17323/1999-5431-2017-0-5-117-133.

\footnotetext{
1 This article is a result of the Basic Research Program Project of the National Research University Higher School of Economics. The authors cordially thank Frederic Jenny for the inspiring presentation on the international experience of excessive price at the Second World Congress of Comparative Economics, which makes the analysis of Russian enforcement in the field in the comparative context possible. The authors express their gratitude to an anonymous referees for their helpful comments and suggestions.
} 


\section{Introduction}

Excessive prices are those exceeding competitive ones. There are several arguments both for and against antitrust enforcement to prevent excessive prices. On the one hand, excessive pricing decreases the consumer surplus and results in welfare losses. On the other hand, interventions against excessive pricing may also result in welfare loss. The consensus is that welfare loss under enforcement against excessive pricing arises because of the high probability of false conviction.

Competition economics consider arguments for and against enforcement regarding excessing pricing, using both normative and positive approaches. A normative approach implies that the enforcement target is a price that definitely exceeds the benchmark price under competition (though imperfect). The main argument for antitrust intervention is an opportunity to increase the consumer surplus.

Nonetheless, there are arguments against intervention as well. The most important is the fear of legal error when the enforcer makes a mistake in deciding that the price is excessive simply because of a high margin, due to a lack of information on what is the 'first best' price under competition. High margins in some industries (for instance, network industries) are necessary for productivity and efficiency. High profits occur as a natural outcome of market forces in such markets. Profits may also by result of innovation and risk taking. Thus, prohibition of excessive pricing would be a disincentive for future innovations and investments. Furthermore, high margins (even from exercising of market power) are attractive to new entrants and any subsequent expansion of competitors might strength competition. From this point of view, and to paraphrase a US Supreme Court quote, charging excessive prices is not only not unlawful, but it is an important element of the free market system.

The most important part of a positive approach to analyzing excessive price enforcement is an evidentiary standard for excessiveness. Even if there are circumstances when regulatory intervention would not undermine economic efficiency, practical difficulties related to determining when a price is excessive arise. Another part of the same issue is establishing what price level is acceptable as a remedy.

Despite the potential criticism, many countries still apply provisions against excessive pricing (Jenny, 2017). The Russian Federation is among them. During the decade from the adoption of the law 'On Protection of Competition' (2006) and a substantial increase in penalty standards (2007), several hundred investigations on excessive pricing have resulted in infringement decisions. However, recently in Russian competition policy there has been a trend towards narrowing the area of enforcement against excessive pricing, and replacing ex-post enforcement in the form of investigations and sanctioning by establishing ex-ante price remedies.

A review of Russian enforcement against excessive pricing allows for answering the question on the role of 'normative' and 'positive' explanations for the increasing skepticism about prohibition on excessive price, or explanations based on the possible welfare effects of enforcement and the available strength of a de- 
terrence. This is the objective of our analysis in the paper. In order to answer the question we analyze enforcement targets, indicators of excessive pricing, and alternative approaches to enforcement that the Russian competition authority applies. In this paper we consider excessive pricing only as 'exploitative' abuse, that is, a 'pure' higher price for customers, in contrast to excessive pricing as a part of 'price squeeze' (a high price for essential input for competitor combined with a low price for the final customers).

The main conclusion is that it is not enforcement targets but standards of proof, which reveal themselves to be the weakest chain of enforcement. A weak deterrence rather than negative side effects explains the shift from ex-post to exante enforcement. A brief review of international experience of similar enforcement in the Member States of the European Union, South Africa and China shows that in many jurisdictions decisions on excessive pricing have little chance of surviving a judicial review. Problems with relevant evidence is not only a Russian curse. The weakness of available standards of evidence explains the decrease of expost interventions, even if the targets of enforcement could be chosen that substantially limit the risk of false conviction (Type I legal error).

The structure of the paper is as follows: Section 2 reviews discussions on enforcement against excessive pricing in law and economics. Section 3 discusses the legal definition of excessive pricing in Russian antitrust law, typical antitrust cases and the main characteristics of enforcement on this issue, and explains the low success of ex-post intervention. Section 4 describes enforcement against exploitative abuse in the form of excessive prices in other countries, especially BRICS, from the angle of Russian experience.

\section{Law and economics of excessive pricing: brief overview}

Market efficiency is at its highest level when prices are competitive. If prices are higher than the competitive level, then total welfare as well as consumer surplus decrease. The excess of the price over marginal costs is the source of profit for the monopolist, which have market power. Of course, not every price that exceeds marginal cost is excessive.

There is a difference between a price that induces a decrease of total welfare in comparison to 'first best' and a price that initiates competition investigations and decisions (Joscow, 2002). In microeconomic theory, the benchmark is a price equal to marginal cost. In competition legislation, the benchmark is a price equal to the price level in the market where there is no dominant company or dominant company not abusing their dominance.

The concept of dominance is one key to proceeding with the discussion between 'non-interventionists' and 'interventionists' about the large proportion of negative effects induced by enforcement against excessive pricing. An important argument against enforcement is that it attempts to prevent high prices impeding incentives to entry (Evans \& Padilla, 2005) and is therefore detrimental in the long-run. Enforcement does not only distort incentives to entry, it is simply not necessary when excessive prices are not sustainable under the threat of potential competition (Fletcher \& Jardine, 2008). 
If these arguments are valid then excessive price is 'self-correcting' and should not be an enforcement target. Nevertheless, what if it is not? Potential entrants may decide not to enter the market if there are high and non-transitory entry barriers (Hou, 2011). Under high entry barriers excessive pricing might be not self-correcting (Ezrachi \& Gilo, 2009). Three of four important market characteristics that justify intervention, according to Motta and de Streel (2007), consider entry barriers:

- High and non-transitory entry barrier in the market;

- Market power originating from current/past exclusive/special rights but not from risky private investments;

- Competition authority has no opportunities to decrease entry barriers.

In turn, high entry cost, or entry barriers that facilitate the influence of a dominant seller, not only on price but also on competition, are an essential part of the dominance concept. If the competition authority applies the appropriate test on dominance correctly, it avoids welfare-detrimental distortions as side effects of enforcement. This seems to have been the case for many of the largest recent investigations into excessive pricing. The most known and widely discussed example is the Mittal Steel decision in South Africa, where the large seller gained dominance due to special rights, historical legal protection and state ownership (Roberts, 2008). A specialized court called this market structure 'super-dominance' or 'quasi-monopoly' (Roberts, 2008; Erzachi \& Gilo, 2009). Under this type of market structure dominance is sustainable and 'incontestable' (Roberts, 2008): high pricing cannot induce entry in the medium-run.

One more side effect of enforcement is possible, in addition to entry deterrence. If the competition authority applies a unit cost as a benchmark to prove excessive pricing, antitrust enforcement can provide the same effects on the incentives to decrease cost and increase productivity as cost-plus price regulation provides. If there is a certain legal cap on the price-cost margin, incentives for cost efficiencies disappear (Laffont \& Tirole, 1986). However, it might not be the case if there is benchmark for price excessiveness that is not related to the cost of a particular company.

Even though, under a particular market structure and the pricing of a dominant company, antitrust intervention can promote welfare, and the competition authority could apply a benchmark that does not distort incentives towards increasing productivity, there is an important group of arguments against such intervention. All of which address the issue of evidentiary standard. There are still no well-defined and workable rules that would allow the comparison of a particular price level with the presumed competitive (or not abusive) price.

Let us bear in mind that European Court of Justice in its seminal decision in the case of United Brands argues that a price is excessive if the pricecost margin is excessive and the price is unfair compared to other prices, which constitutes the two-stage test. The first stage is to calculate the profit margin (price-cost margin) and assess whether the margin is excessive. Methods that could be applied to the analysis of price-cost margin at this stage are discussed widely (O'Donoghue \& Padilla, 2006). It is unclear how to assess any unfairness of prices at the second stage. Comparison of the past prices of a dominant seller 
in the same market, current prices of other products of a dominant seller in the same market, current prices of competitors in the same market, current prices of a dominant seller for the same relevant product in another geographical market, prices of a dominant seller for the related product in the same market, and prices of comparable product of the dominant seller are all options for benchmarking (Hou, 2011).

Suggestions in regards to assessing the (un)fairness of a price may also include the direct comparison of the changes in the surplus of buyer and seller (see for instance, dual entitlement approach by Akman \& Garrod, 2011). Some authors even propose to eliminate this stage and to define excessive prices as being significantly above the minimum average cost (Motta \& de Streel, 2006).

At both stages the price and performance indicators of a dominant seller should be compared with some benchmark. The following conditions should be observed in order to ensure that the comparison is objective (Evans \& $\mathrm{Pa}$ dilla, 2005):

- clear determination of which indicators are to be compared (only prices or profit as well);

- choice of an unambiguous benchmark (the marginal cost, prices of competitors, or the price assigned by the same seller in another market etc);

- choice of threshold level for allowable excess of benchmark;

- ensure that the principle "other things equal" with respect to all factors affecting demand and costs is met.

A number of benchmarks could be used. Price-cost comparison suggests price analysis in relation to a relevant cost measure. Here problems arise with the choice of a threshold price and with the costs calculation since there are different economic concepts of costs. Profit rates are often suggested to be a benchmark, but profitability measures are usually influenced by accounting conventions. Moreover, the analysis of excessive return, that is the difference between the rate of profit and the cost of capital, may lead to wrongful conviction. A company may have a higher internal rate of return (IRR) than competitors or companies in other sectors due to good business reasons. It means that companies with similar cost profiles may have different IRRs (Grout \& Zalewska, 2007). Another approach allows for comparing prices with those of competitors. However, consumers may buy products at higher prices if they consider them to have competitive advantages. The price in international markets could also be a benchmark, though price discrimination across regions does not necessarily harm consumers (at least unless we are not in the country with highest price). Finally, the regulator may use the earlier prices of a dominant firm for such a comparison, but there is no guarantee that they were not below the competitive level.

Thus, any analysis of excessive prices, in practice, may lead to mistakes. There is no definition or benchmark that permits identifying excessive pricing without possible legal errors, including Type I error (false conviction) and Type II error (false acquittals). Both types of errors limit the deterrence effect of legal rules.

In addition, legal errors induce side effects contributing to the social cost of enforcement. Under the positive probability of errors, not only do the participants of particular litigation bear additional costs. This is also true for every 
dominant seller. The cost of legal errors may be explicit or implicit. The explicit cost of Type I errors includes expenses on investigations and litigation. Distortions of the decisions of a dominant seller due to the probability of expected litigation bring an implicit cost of errors. The second part of the cost includes, among other things, the negative effects of errors in litigation on investments and innovation due to the decrease in the expected rate of return in the companies, which are potential targets for investigation. Let us remind that it is a convention that the largest social cost of Type I error in enforcement against excessive pricing is due to the suppression of incentives to entry. It may be true not only for the market under investigations but also for other markets where potential entrant may appear dominant at some point.

The cost of a Type II error (when excessive prices are unpunished) constitutes the loss of consumer welfare, where some consumers buy goods and services at higher prices than in an otherwise competitive market, while others are forced to refuse to buy goods and services (Evans \& Padilla, 2005). To sum up, the costs of legal errors reduce the positive welfare effects of antitrust intervention for affected companies and limit deterrence for all dominant market participants.

There is no commonly accepted indicator of the magnitude of the probability of Type II errors. However for the probability of a Type I error a relevant indicator exists. The high probability of a possible error in terms of false convictions (Type I error) is revealed in the likely annulment of the decision under judicial review (in the administrative enforcement system) or by the responsible court (in the prosecutorial system). Let us remind ourselves that the South African Competition Appeal Court annulled the previously mentioned Mittal decision because of the unconvincing test for price excessiveness. Competition economists consider this decision as an example of the deep coherent economic analysis that contributes to the increase of evidentiary standards (Calcagno \& Walker, 2010). We may however consider this case from another angle. If a test for price excessiveness, which includes a reasonable level of doubt, does not exist, deterrent effect of enforcement is necessarily low. Because of this, enforcement against excessive price does not make sense.

The competition authority, choosing the scope of the intervention against excessive pricing, takes into account both expected welfare effects and strength of deterrence. Strength of deterrence depends on whether the method of establishing price excessiveness is able to distinguish between 'legal' and 'excessive' price as an abuse of dominance correctly. The low discriminative quality of tests undermines the positive welfare effects of enforcement.

It is necessary to stress that legal errors in the investigations against excessive pricing may arise because of the low discriminative quality of two types of tests the test on dominance and the test of price excessiveness. In order to assess enforcement targets and enforcement effects in a particular country, it is necessary to distinguish between these two tests. A large proportion of the arguments of noninterventionists address the issue of markets not being able to pass a 'structural test' for dominance. For instance, the argument on entry prevention is valid only in those markets where high profit induces effective entry. In many jurisdictions this would not be the case, simply because a large company in a market with low 
entry barriers is not qualified as a dominant ${ }^{2}$. However even if a structural test works well, the inability to identify the level of 'normal' price and therefore excessive price with a reasonable level of certainty may result in low deterrence effects.

\section{"Excessive pricing" concept in Russia}

\section{Legal definition}

In Russian antitrust legislation the definition of excessive pricing (in terms of Russian competition legislation - monopolistically high price) has changed over time. The starting point was its definition in law 'On Competition and Restriction of Monopolistic Activities', which was in force from 1991 to 2006. This law defined an excessive price as the price of a dominant seller exceeding the price, set in comparable conditions, but in a competitive environment. The subsequent version of the law (Federal law 135 of 26.07.2006 'On Protection of Competition'), adopted in 2006, widened this definition. According to Article 6 of this law, an excessive price is a price established by a dominant seller that satisfies two criteria: (1) the price exceeds the sum of cost and profit necessary for production and distribution and (2) the price exceeds the price established under similar demand and supply conditions in the comparable competitive market. Ideally, to reach a conclusion on excessive pricing, the competition authority should prove that both criteria are satisfied. The Supreme Commercial Court of the Russian Federation in 2010 established the rule that the first criterion could be applied alone only if there are no comparable markets where price could be used as a benchmark. Price established by sector regulators, price of commodities market and price on IPRs are safe harbors for an investigation into excessiveness.

In 2009, the competition authority introduced the 'dynamic test', according to which a price is considered to be excessive if it remains constant while prices of inputs decrease, or it increases faster than input prices or if the price increases under non-changing input prices and demand conditions. Changes in the law reflect the non-satisfactory outcomes of all the applied tests on price excessiveness.

\section{Enforcement}

From 2008 to 2015, 105 infringement decisions by the Russian competition authorities on excessive pricing (high monopolistic price) as a form of abuse of a dominant position were appealed in the commercial courts ${ }^{3}$ - this was about $9 \%$ of all appealed decisions where competition issues were at stake. Taking into account that about every third competition infringement decision is appealed, this amounts to about 35 decisions annually.

\footnotetext{
2 Russian legislation is not an exception. A large company with a market share exceeding $50 \%$ has the right to prove the absence of dominance. The most important reason for this is low entry cost. There are examples when competition authorities refrain from qualifying as dominant large participants in the market with low entry cost, using the argument of contestability.

3 In Russia, competition policy is organized as an administrative enforcement. The competition authority (FAS), including the Central Office and regional subdivisions, investigates and makes decisions on infringements. Any company found to be infringing has the right of appeal in order to annul the FAS decision in a commercial court. Costs of litigation are relatively low in Russia. Thus most companies, which consider themselves to be convicted erroneously, submit appeal claims.
} 
Russian antitrust enforcement is only a partly centralized system. Regional subdivisions of the Federal Antitrust Service are sufficiently independent from the Central Office. The structure of enforcement targets, economic analysis and development of evidence in its cases may substantially vary from one regional division to the other. We concentrate mostly on the decisions of the Central Office.

\section{Selection of enforcement targets}

Under the Russian provisions for the enforcement regarding excessive pricing, two groups of targets are most important. The first group is large exporters, who are dominant in the domestic market. Large-scale mergers after privatization has improved international competitiveness of Russian companies, but at the same time has also increased their power in domestic markets (Avdasheva \& Tsytsulina, 2015). A large proportion of exporting companies discriminate against Russian downstream customers vis-à-vis customers abroad by systematically setting higher prices (Golovanova, 2010). The most high-profile case concerned oil companies, which have a persistent dominant position in the domestic market historically. The FAS accused the 'Big Four' Russian suppliers of motor fuel (Gazpromneft, Lukoil, Rosneft and TNK-BP (acquired by Rosneft in 2013)) of excessive pricing as a form of abuse of their collective dominance in 2008-2009. The main test for price excessiveness was the asymmetric pass-through of world oil prices on domestic wholesale fuel prices. When world oil prices rise, domestic wholesale prices increase more rapidly, while when world oil prices fall, domestic wholesale prices decrease more slowly. The FAS imposed a huge fine of 26 billion rubles (approximately US\$1 billion) on the companies.

The FAS initiated similar investigations, where the main evidence was higher prices in the domestic market vis-à-vis export prices, into large exporters of other primary products. One remarkable case concerned the Novolipetsky metallurgical plant, one of the largest cold-rolled steel producers worldwide. Its market share in the domestic market is almost 100 per cent. In 2012 the plant was accused of imposing a excessive price for cold-rolled grain-oriented steel. The evidence was based on the disparity between the trends in export and domestic prices, and between the changes in production cost and the domestic price. After a judicial review over several instances ${ }^{4}$, these arguments did not convince the court of cassation, and the court finally annulled the infringement decision. Another example was the accusations against Raspadsky Coal Company for the unjustified establishing of various prices for concentrates of coal. The FAS showed that the difference in commodity prices for Russian and foreign consumers in OctoberNovember 2009, reduced to a single delivery basis (FCA departure station), was about $48 \%$. Again, the court annulled the decision in the end for the reason that setting different prices in different market is not an unlawful practice.

The second important group of targets is sellers in deregulated markets. The typical context for investigations into excessive pricing is similar to investigations

\footnotetext{
4 There were six court decisions on this case. After the commercial court of first instance, appeal and cassation instances supported the conclusion of the FAS on excessive pricing, the Supreme Commercial Court decided that all these courts had not implemented important substantial tests and sent the case to the first instance court again. Finally, under the second round of the judicial review the cassation instance annulled the decision.
} 
into the refusal to deal by the operators of essential facilities (Golovanova, 2013). Recent cases (2016-2017) are the investigations and decisions on stevedoring companies (cargo terminals) including Novorossiysk Commercial Seaport, Global Ports, and Universal Cargo Logistics Holdings companies. Until 2013-2014, rates for cargo services were regulated and set in dollars. After deregulation, which coincided with the depreciation of the national currency, prices for stevedoring services in Russian ports increased in line with the ruble depreciation rate - by 2.5 times on average. Complaints from large exporters and the national rail operator resulted in an investigation. The FAS found most stevedoring companies guilty of abusing a dominant position in a form of excessive pricing in the markets for the transshipment of different commodities, such as ore, fertilizers, containers, ferrous and non-ferrous metals, oil and fuel. The conclusion on excessive pricing relies on the analysis of margin-cost ratios. As a result, the FAS fined the accused companies around 17 billion rubles (approximately US $\$ 0.3$ billion) and imposed remedies in order to convert rates into rubles $^{5}$. In June 2017, the commercial court of the first instance annulled one of the decisions against one oil cargo terminal. There are reasons to expect that the judicial review will be long and difficult. Similar examples of cases concerning the excessive pricing of interconnection in telecommunications were held several years ago (see Krychkova, 2013, in Russian). In these cases the courts also annulled the bulk of the decisions made against excessive pricing on interconnection.

Table 1

\section{Targets of enforcement and options of evidence under enforcement against excessive pricing}

\begin{tabular}{|l|l|l|l|l|}
\hline \multicolumn{1}{|c|}{ Targets } & $\begin{array}{c}\text { Relevant } \\
\text { theory of harm }\end{array}$ & $\begin{array}{c}\text { Observed } \\
\text { indicators } \\
\text { of consumer } \\
\text { surplus loss }\end{array}$ & $\begin{array}{l}\text { Companies under } \\
\text { investigation } \\
\text { (markets affected) }\end{array}$ & $\begin{array}{c}\text { Type of analysis } \\
\text { (benchmarks) }\end{array}$ \\
\hline $\begin{array}{l}\text { Exporters } \\
\text { of primary } \\
\text { products and } \\
\text { participants } \\
\text { of adjacent } \\
\text { markets }\end{array}$ & $\begin{array}{l}\text { Third-degree } \\
\text { price discrimi- } \\
\text { nation }\end{array}$ & $\begin{array}{l}\text { Domestic price } \\
\text { exceeds export } \\
\text { prices }\end{array}$ & $\begin{array}{l}\text { Largest oil companies } \\
\text { ('Big Four'), 2008- } \\
\text { 2009 (motor fuel) } \\
\text { Novolipetsky } \\
\text { metallurgical plant, } \\
\text { 2009-2011 (colled- } \\
\text { rolled steel) } \\
\text { Raspadskaya Coal, } \\
\text { 2008-2009 (concen- } \\
\text { trated coal) }\end{array}$ & $\begin{array}{l}\text { Unit cost } \\
\text { Price of dominant } \\
\text { sellers in other mar- } \\
\text { kets (abroad) } \\
\text { Past price of domi- } \\
\text { nant sellers in domes- } \\
\text { tic market }\end{array}$ \\
\hline $\begin{array}{l}\text { Dominant com- } \\
\text { panies in the } \\
\text { markets after } \\
\text { deregulation }\end{array}$ & $\begin{array}{l}\text { Sustainabil- } \\
\text { ity of natural } \\
\text { monopoly and } \\
\text { excessive price }\end{array}$ & $\begin{array}{l}\text { Substantial } \\
\text { price increase } \\
\text { after deregu- } \\
\text { lation }\end{array}$ & $\begin{array}{l}\text { Cargo terminal opera- } \\
\text { tors: from 2016 (after } \\
\text { price deregulation } \\
\text { in 2014) } \\
\text { Megafon, BeeLine } \\
\text { (2010-2012) }\end{array}$ & $\begin{array}{l}\text { Unit cost } \\
\text { Price of (regulated) } \\
\text { competitors in other } \\
\text { markets } \\
\text { Past price of domi- } \\
\text { nant sellers (before } \\
\text { deregulation) }\end{array}$ \\
\hline
\end{tabular}

Source: The table is created by the authors.

\footnotetext{
5 "FAS ordered four stevedores to transfer almost 17 billion rubles to the budget for abuse of dominant position”. 2017. Available at: http://fas.gov.ru/press-center/news/detail.html?id=49561 (in Russian).
} 
A common feature of both targets is that the theories of harm to consumers are straightforward. For the first group, the theory of harm is the third-degree price discrimination of domestic customers vis-à-vis export commodity markets. The pricing observed is very close to the 'import parity' pricing system in the Mittal case in South Africa (Roberts, 2008): a large exporter establishes, in the domestic market, a price that is low enough to prevent profitable import. Such a policy results in a substantial decrease of consumer surplus within domestic market boundaries. It is also important that there are no circumstances under which third-degree discrimination brings additional surplus to domestic customers. The same is true for the sellers in the market with unsuccessful deregulation, when competition does not arise. Market structure and harm to consumers may justify antitrust enforcement. Moreover, for large exporters, distorting the effect on incentives for cost-minimization is unlikely. Competition in relevant international markets is sufficient to incentivize an increase in productivity and a decrease in costs.

\section{Standards of evidence}

The Russian competition authorities have made substantial efforts to develop convincing standards of proof in cases regarding excessive pricing. The FAS elaborated several guidelines to explain in more detail the approaches to assess market comparability (Shastitko, 2010) and to calculate cost and profit necessary for production.

In September 2014, the Presidium of the FAS approved the 'Principles of Economic Analysis of Pricing Practices' (hereinafter referred to as the Principles) for their compliance with the law 'On Protection of Competition'. The idea of the Principles is that prices in the Russian markets will change in accordance with international market prices. As a result, domestic buyers of the products of exporting companies, that obtain a dominant position in the domestic market, benefit, because the terms of their contracts would be no worse than for foreign buyers of the same suppliers.

The Principles allows the FAS to use indicators of world market prices, such as the prices of spot contracts, export contracts prices and other over-the-counter indicators, for the application of comparable markets concept. In fact, the indicators mentioned are not always a result of competition. In some cases, they are amenable to manipulation by the market participants, especially if the number of producers in the markets is not high. Regardless, the FAS usually considers world markets as comparable for almost all cases against exporters and make a comparison of prices as noted by Hou (2011). Prices of the company under investigation are compared with prices of the same supplier in markets abroad. This was true in the cases of Novolipetsky metallurgical plant and the oil companies (Table 1).

Another standard of evidence includes the cost and profit necessary for production. There are two documents devoted to the calculation of costs and profits necessary for production and distribution. The 'Scientific and practical commentary to the Federal law 'On Protection of Competition" (2015) clarifies among others:

- the approach to the comparison of profit to cost margin over time;

- the approach to the comparison of profit to cost margin of dominant sellers with the profit to cost margin of other sellers in comparable markets;

- the approach to taking into account differences in productivity. 
The explanatory note of the Presidium of the FAS - 'Definition of monopolistically high and low price of goods' (2016) - establishes that costs are recognized as costs in the reporting period in which they occurred, regardless of the time, explicit monetary payment and other forms of implementation. In this way, the competition authority allows for taking cost, not only in explicit but also in implicit form, into account. The analysis should cover not only prices, costs and profits, but also the excess of actual profitability over the normative indicators of profitability for those markets where the level of profitability is established normatively (for instance, under regulation). While determining the economic feasibility of the costs, the authority may compare the changes in similar costs of the undertaking in the production of other goods and the changes in similar costs in other sectors. For example, the comparison may consist of the cost of raw materials for the production of a commodity sold by dominant seller and the cost of similar raw materials for the production of goods sold under competition. The absence of reasonable economic explanation of costs for production can serve as a basis for recognizing the price to be excessive.

The elaboration of guidelines followed the application of methods to prove excessive pricing. In their investigations into excessive price during the last decade, the FAS applied nearly every approach that international experience suggests (How, 2011). In most cases this meant not just one but several approaches (see Table 1). The commercial courts found none of them sufficiently convincing and annulled most of decisions made. The only exceptions were cases in the oil sector, when the Supreme Commercial Court of the Russian Federation supported the FAS decision on the excessive price of motor fuel in the TNK-BP (2010) case. Even in this case, which is very politically sensitive, not all the commercial courts support infringement decisions. The difference between the decisions of regional courts of first instances, and courts of first instance and appeal courts, and then appeal and cassation courts, shows that the FAS approach is not very persuasive to judges (Avdasheva \& Golovanova, 2017).

In many cases the reason for annulling an infringement decision was a failed structural test for dominance. However, in general, courts are more often satisfied with the analysis of market competition and dominance than with the analysis of prices and cost.

\section{Enforcement}

There are two possible enforcement options: to implement it ex-post (when the regulator makes infringement decisions and obliges penalties) or ex-ante (the regulator prepares price remedies to prevent possible infringements). The Russian competition authority applies both, yet over time it has preferred the second.

Excessive price investigations and decisions have resulted in the largest monetary penalties. For example, for oil companies this has amounted to approximately US $\$ 1$ billion, for stevedoring companies - US $\$ 0.3$ billion. Fines are calculated based on either turnover (oil companies) or illegal gains (excessive profit) expropriation (recent examples being the stevedoring companies). The second approach is explained by the desire to avoid a distortive impact on output and prices (Bageri et al, 2013). 
In the recent years, there has been a shift towards extensive price remedies. Usually remedies establish price caps and permitted price variation across groups of consumers. The regulator uses prices in the international markets or the export contracts of a dominant seller as benchmarks (Avdasheva \& Radchenko, 2017, forthcoming).

The FAS applied remedies to those sellers who dominate unilaterally (Uralkali in the market of basic fertilizers, RUSAL in the market of primary aluminum), and also in oligopoly markets (LUKOil, Rosneft, and Gazpromnetf in the motor fuel markets). Typical targets of remedies are large producers of exported products. Thus, remedies attempt to prevent discrimination of customers in the domestic market within the model of third-degree price discrimination.

FAS can either establish remedies themselves or ask companies to elaborate remedies for approval. In recent years the FAS has required producers to develop and implement 'commercial policy', which should be approved by the competition authority. These represent guidelines regulating all aspects of transactions with customers, including pricing - 'not to establish the same level of retail prices', 'not to make economically unreasonable simultaneous changes in retail prices' and 'to follow cost-based pricing' (Avdasheva \& Golovanova, 2017). Large oil companies and suppliers of potash fertilizer, caustic soda and other industrial inputs developed such commercial policies in Russia. It is difficult to estimate the overall effect of such remedies. The immediate effects are based on the redistribution of a surplus towards a target group of market participants. Negative side effects of remedies are also possible (Avdasheva \& Radchenko, 2017, forthcoming), but until recently there was no relevant empirical evidence to prove their emergence.

\section{Excessive pricing in case law of other countries:}

perspective from Russian experience

Any comparison of Russian enforcement against excessive pricing with similar types of enforcement abroad is limited because of the great divergence in competition legislation in this regard. In the US there are no provisions against excessive pricing by dominant companies. This is in line with the concept of self-correcting price. In contrast, European Union legislation introduces illegality of excessive pricing as particular types of unfair prices. Member States follow this approach. Most other competition jurisdictions worldwide, including BRICS share the EU but not the US approach. One important exception among BRICS is Brazil, where legislators recently excluded provisions on excessive pricing from the national law.

In the EU member states and also in South Africa and China, in spite of substantial differences in tests to establish excessive pricing (Jenny, 2017) the authorities apply provisions against the same group of companies as in Russia, including exporters of primary products, natural resources sellers, and companies in deregulated industries.

In the EU a large percentage of infringement decisions on excessive pricing are against companies in deregulated industries. The Commission accused Deutsche Post of excessive pricing for delivering cross-border mail because the price was equal to delivering domestic mail but the cost was less due to the oppor- 
tunity to collect mail ${ }^{6}$. Another example is the case against the Port of Helsingborg ${ }^{7}$. The Commission concluded that the port charges resulted in excessive revenues from ferry operations. This is the only case made by the Commission through cost accounting and examining an excessive profit margin. The potential comparability with another port was rejected by the Commission due to differences in infrastructure and the number of services offered by the two ports.

In South Africa there have been at least two high-profile cases against exporters of primary products which obtained a dominant position in the domestic markets, very similar to the Russian investigations into the producers of motor fuel and steel. Competition Tribunal made (in 2009) an infringement decision accusing Mittal Steel South Africa Limited of excessive pricing in regards to flat steel products in the domestic market ${ }^{8}$. The Tribunal argued that excessive pricing was induced by Mittal's 'super dominant' position as an 'uncontested firm in an incontestable market'9. However, the Competition Appeal Court annulled the decision because it did not contain a comparison or analysis of price with reasonable economic value.

Another infringement decision regarding excessive pricing in South Africa was made in 2014 against Sasol, a producer of purified propylene and polypropylene $^{10}$. Sasol obtains a cost advantage in these products production since propylene is a by-product of coal-to-liquid fuel production. The Tribunal argued that Sasol's prices to customers in the domestic market exceeded Sasol's actual cost of producing purified propylene and polypropylene, including the cost of capital. Additionally, for polypropylene, the Tribunal found that Sasol's pricing to domestic customers was higher than the deep sea export price and the prices in Western Europe for polypropylene.

The outcomes from enforcement against excessive pricing in the jurisdictions mentioned are also similar. Decisions on excessive pricing have little chance of surviving a judicial review, mostly because the courts consider evidence of excessiveness to be non-convincing. In EU, infringement decisions are sustainable only in those Member States where there is no tradition of judicial revision (Svetlicinii \& Botta, 2012). This is also the case outside Europe. As it was already mentioned, the infringement decision against Mittal was reversed by the Competition Appeal Court, obliging the Tribunal to assess prices on the basis of more reliable test.

Furthermore, in many countries there is a shift to remedies, being either complementary to monetary penalties or substituting them, as in Russian Federation. Consider for instance the high-profile case of Qualcomm, a leading U.S. semiconductor and telecommunications equipment producer. In 2015, the Chinese competition authority fined Qualcomm for abuse of a dominant position in the form of excessive pricing, unfair terms and bundling. The violation consisted in exces-

\footnotetext{
6 Case COMP/C-1/36.915

Case COMP/A.36.568/D3

8 70/CAC/APR07. Available at http://www.comptrib.co.za/list_judgement.asp?jid=1049

9 "Staying safe - dominant firms' pricing decisions in industries where high prices do not attract entry" Louise du Plessis and Lizél Blignaut. Third Annual Competition Commission, Competition Tribunal and Mandela Institute Conference on Competition Law, Economics and Policy in South Africa.

${ }^{10}$ Competition Commission vs Sasol Chemical Industries, case no 48. CR. Aug 10.
} 
sive royalties for mobile device manufacturers in China, since the Anti-Monopoly Law in China prohibits selling products "at an unfairly high price". In particular, Qualcomm did not provide customers with a list of all patents from a licensing package, including patents that had already expired. Qualcomm was found guilty in offering unfair cross-licensing conditions and setting the royalty rate at a high level. Qualcomm was obliged to follow a set of remedies, including the calculation of the royalty rates based on $65 \%$ instead of $100 \%$ of the wholesale price of handsets in China, which is essentially a kind of price cap ${ }^{11}$. In South Africa, in the Sasol case behavioral remedies supplemented monetary fines. Sasol was required to set a price based on a forward-looking principle without the discrimination of any groups of customers in any markets.

Thus, Russian provisions for the enforcement of excessive pricing have a number of similarities with other jurisdictions. Worldwide, competition authorities who tend to apply provisions against supra-dominant companies in the markets with high entry barriers face serious problems in proving price excessiveness. The authorities try to substitute infringement decisions that a company can successfully appeal for the use of commitments, settlements and remedies. Our explanation of this shift is the high cost of investigations due to the absence of a convincing test for price excessiveness together with the non-satisfactory outcomes of judicial reviews of infringement decisions.

\section{Conclusion}

In Russia, the high concentration and market power in those sectors which are most important for international trade, together with the experience of price regulation and deregulation, explain the approach to enforcement against excessive pricing. The FAS applies two tests to price excessiveness - the comparable markets and the cost plus approach - and is making efforts to develop both of them. Low satisfaction with the outcomes of traditional enforcement using penalties results in the extensive development of ex-ante price remedies. In general, this field of antitrust enforcement addresses similar targets and faces similar difficulties as other countries that apply provisions on excessive pricing, including the Member States of the European Union and, principally, the BRICS countries. Neither typical targets, nor methodological issues, nor applications of behavioral remedies are idiosyncratic to Russian competition enforcement.

However it is far from clear whether or not enforcement satisfies the criteria of the combination of large losses from high price avoidance and the reasonably low cost of competition enforcement. Two groups of reasoning oppose enforcement as a possible welfare-detrimental: the first is a trade-off between static and dynamic efficiency, and the second is the absence of satisfactory legal standard for establishing price excessiveness.

Both issues could appear independently but they could also be interrelated. Punishment for high prices and high profits caused by high prices may prevent

\footnotetext{
${ }^{11}$ Antitrust in China: NDRC v. Qualcomm - One All. Allen \& Overy. 12.02.2015. Available at: http://www. allenovery.com/publications/en-gb/Pages/Antitrust-in-China-NDRC-v--Qualcomm---One-All.aspx
} 
entry if a Type I legal error occurs regardless of the approach to establishing price excessiveness. Use of high price-cost margins as an indicator of excessive pricing suppresses incentives towards cost-efficiency. In the latter case, an imperfect measurement approach reinforces distortions of the incentives. The importance of these two groups of considerations for Russian competition enforcement differs.

Until recently, concerns about undermining the incentives for cost efficiency and investments were not relevant to a large proportion of enforcement targets in Russia. Large exporting companies, which are targets of excessive price investigations (including exporters of metals, coal, oil and petrol products), have high incentives to increase cost efficiency due to competition in the global commodity markets. This statement is not so evident for the second group of targets, which are companies in deregulated industries (for instance, cargo terminals).

The analysis of Russian case law confirms well-known difficulties in defining excessive prices in practice. There is no clear and convincing criterion for excessive prices since it is unclear which standard to use for comparison of the actual set price, to what extent profit indicators can be used, and what excess of the actual set price over the benchmark is necessary for the qualification of the price to be excessive. During last decade, the FAS applied nearly all the possible criteria for establishing price excessiveness that is mentioned in the literature and applied in other jurisdictions. Among these, comparison of the price in question with the price of a dominant seller in another market provokes less criticism. Paradoxically the Supreme Commercial Court of the Russian Federation rejects exactly this criterion with the statement that any seller has a right to set different prices in different markets under different demand conditions. All other methods applied caused criticism, which explains the fact that courts annulled more than half of all the decisions made by the competition authority on excessive prices in 2008-2015.

Russian experience shows that irrespective of all other problems, legal rule in competition enforcement against excessive pricing is the weakest point. If the standards for establishing excessive pricing are high enough to avoid Type I error, it is very unlikely to support a conclusion on excessive pricing with a satisfactory level of confidence. As a result, probability of detection as well as deterrence decreases. In turn, a decrease in the standard may result in the increased probability of Type I error that is again detrimental to deterrence. This tradeoff explains the non-satisfaction of competition authorities with the outcomes of enforcement against excessive pricing and the recent shift to ex-ante behavioral remedies. 


\section{REFERENCES}

1. Akman, P. \& Garrod, L. (2011). When are Excessive Prices Unfair? Journal of Competition Law and Economics, vol. 7, no 2, pp. 403-426.

2. Avdasheva, S. \& Golovanova, S. (2017). Oil Explains All: Desirable Organisation of the Russian Fuel Markets (On the Data of Three Waves of Antitrust Cases Against Oil Companies). Post-Communist Economies, vol. 29, no 2, pp. 198-215.

3. Avdasheva, S., Golovanova, S. \& Korneeva, D. (2016). Distorting Effects of Competition Authority's Performance Management: The Case of Russia. International Journal of Public Sector Management, vol. 29, no 3, pp. 288-306.

4. Avdasheva, S. \& Tsytsulina, D. (2015). The Effects of M\&As In Highly Concentrated Domestic Vis-À-Vis Export Markets: By the Example of Russian Metal Industries. Research in International Business and Finance, vol. 34, pp. 368-382.

5. Avdasheva, S. \& Radchenko, T. (2017, forthcoming). Remedies in BRICS countries: are there lessons from and for competition economics? In: Competition Policy for the New Era: Insights from BRICS and Developing Countries (eds. T. Bonakele, E. Fox, L. Mncube). Oxford University Press.

6. Bageri, V., Katsoulacos, Y. \& Spagnolo, G. (2013). The Distortive Effects of Antitrust Fines Based on Revenue. Economic Journal, vol. 123, no 11, pp. 545-557.

7. Calcagno, C. \& Walker, M. (2010). Excessive Pricing: Towards Clarity and Economic Coherence. Journal of Competition Law and Economics, vol. 6, no 4, pp. 891-910.

8. Evans, D. \& Padilla, A. (2005). Excessive Prices: Using Economics to Define Administrable Legal Rules. Journal of Competition Law and Economics, vol. 1, no 1, pp. $97-122$.

9. Ezrachi, A. \& Gilo, D. (2009). Are Excessive Prices Really Self-Correcting? Journal of Competition Law and Economics, vol. 5, no 2, pp. 249-268.

10. Fletcher, A. \& Jardine, A. (2008). Towards an appropriate policy for excessive Pricing. In: European Competition Law Annual 2007: A Reformed Approach to Article 82 EC (eds. Ehlermann C., Marquis M.) Oxford, Hart Publishing, p. 533.

11. Golovanova, S. (2014). Legal Structure of Comparable Markets in the Russian Antimonopoly Legislation. Ekonomicheskaya politika, no 5, pp. 99-115 (in Russian).

12. Golovanova, S. (2013). Competition Restriction Problem in the Markets Linked to the Markets of Essential Facilities. Journal of the New Economic Association, no 20, vol. 4, pp. 110-132 (in Russian).

13. Golovanova, S. (2010). Evidence on Imperfect Competition: Prices of Exported and Imported Goods in Russia (in Russian). Journal of Modern Competition, no 22, vol. 4, pp. 11-25 (in Russian).

14. Grout, P. \& Zalewska, A. (2008). Measuring the Rate of Return for Competition Law. Journal of Competition Law and Economics, vol. 4, no 1, pp. 155-176. 
15. Hou, L. (2011). Excessive Prices within EU Competition Law. European Competition Journal, vol. 7, no 1, pp. 47-70.

16. Jenny, F. (2017) Abuse of Dominance by Firms Charging Excessive or Unfair Prices: an Assessment. Paper presented at Second World Congress of Comparative Economics, St Petersburg, 15-17 June 2017.

17. Joskow, P.L. (2002). Transaction cost economics, antitrust rules, and remedies. Journal of Law, Economics, and Organization, vol. 18, no 1, pp. 95-116.

18. Kryuchkova, P. (2013). Regulation of Prices for Call Termination Services on the Network Telephone Operator: Antitrust or Tariff Regulation? Ekonomicheskaya politika, no 6, pp. 126-142 (in Russian).

19. Laffont, J.J., \& Tirole, J. (1986). Using Cost Observation to Regulate Firms. Journal of Political Economy, vol. 94, no 3, Part 1, pp. 614-641.

20. Motta, M. \& de Streel, A. (2006). Excessive Pricing and Price Squeeze under EU Law. In: European Competition Law Annual 2003: What Is an Abuse of a Dominant Position? (eds. Ehlermann C., Atanasiu I.) Oxford: Hart Publishing.

21. Motta, M. \& de Streel, A. (2007). Excessive Pricing in Competition Law: Never Say Never? In: The Pros and Cons of High Prices, Kalmar: Swedish Competition Authority, pp. 14-46.

22. O'Donoghue, R. \& Padilla, A. (2006). The Law and Economics of Article 82 EC. Oxford: Hart Publishing.

23. Roberts, S. (2008). Assessing Excessive Pricing: The Case of Flat Steel in South Africa. Journal of Competition Law and Economics, vol. 4, no 3, pp. 871-891.

24. Shastitko, A. (2010). 'Comparable Markets' as an Instrument of Antimonopoly Policy. Voprosi ekonomiki, no 5, pp. 96-109 (in Russian).

25. Svetlicinii, A. \& Botta, M. (2012). Article 102 TFEU as a Tool for Market Regulation: "Excessive Enforcement" Against "Excessive Prices" in the New EU Member States and Candidate Countries. European Competition Journal, vol. 8, no 3, pp. 473-496. 